\title{
IMPLEMENTASI ALGORITMA CLUSTERING PARTITIONING AROUND MEDOID (PAM) DALAM CLUSTERING VIRUS MERS-CoV
}

\author{
Septian Wulandari ${ }^{1}$, Nurfidah Dwitiyanti ${ }^{2}$ \\ Informatika, Universitas Indraprasta PGRI Jakarta \\ septian.pmb09@rocketmail.com
}

Submitted June 13, 2020; Revised July 25, 2020; Accepted August 1, 2020

\begin{abstract}
Abstrak
Middle East Respiratory Syndrome Coronavirus (MERS-CoV) merupakan suatu penyakit saluran pernapasan yang disebabkan oleh virus corona. Virus ini merupakan virus yang mudah menular, namun penularannya tidak semudah flu biasa, melainkan virus MERS-CoV lebih rentan menular melalui kontak langsung, misalnya pada orang yang merawat penderita virus MERS-CoV tanpa menerapkan prosedur perlindungan diri terhadap virus dengan baik. Untuk mengetahui karakteristik, penyakit virus MERS-CoV dapat diketahui dengan mengidentifikasikan DNA (deoxyribonucleic acid). Salah satu teknik dalam mengidentifikasi karakteristik makhluk hidup adalah dengan melakukan clustering. Clustering dapat dilakukan dengan mengelompokkan DNA menjadi kelompok-kelompok yang memiliki kesamaan sifat dan fungsinya. Algoritma clustering yang digunakan pada penelitian ini adalah Partitioning Around Medoid (PAM). Algoritma ini memiliki kelebihan yaitu hasil proses clustering tidak bergantung pada urutan masuk dataset dan mengatasi sensitive terhadap noise dan outlier. Tujuan penelitian ini adalah untuk melakukan implementasi algoritma clustering Partitioning Around Medoid (PAM) dalam clustering virus MERS-CoV. Penelitian ini dilakukan melalui pendekatan studi literatur deskriptif kuantitatif. Implementasi algoritma PAM terhadap barisan DNA MERS-CoV diperoleh 2 cluster dengan nilai silhouette coefficient yang tertinggi berada pada jumlah cluster 2 yaitu 0,61534. Jumlah anggota pada Cluster 1 adalah 84 barisan DNA MERS-CoV dan jumlah anggota pada Cluster 2 adalah 16 barisan DNA MERS-CoV.
\end{abstract}

Kata Kunci : MERS-CoV, Clustering, Partitioning Around Medoid (PAM)

\begin{abstract}
The Middle East Respiratory Coronavirus (MERS-CoV) is a disease caused by a coronavirus. This virus is contagious, but its transmission is not as easy as the common cold, MERS-CoV virus is better susceptible to transmitting through direct contact, for example in people who care about the MERSCoV virus without the need for virus protection. To determine the characteristics, the MERS-CoV disease virus can be identified by identifying DNA (deoxyribonucleic acid). One technique in understanding the characteristics of life is by grouping. Grouping can be done by grouping DNA into groups that have attributes and functions. The Clustering algorithm used in this study is Partitioning Around Medoid (PAM). This algorithm has the advantage that the results of the grouping process are not by following the order of entering the dataset and overcome sensitivity to noise and outliers. The purpose of this study is to implement the Partitioning Around Medoid (PAM) clustering algorithm in clustering the MERS-CoV virus. This research was conducted through a quantitative descriptive literature study. The implementation of the PAM algorithm on the MERS-CoV DNA sequence obtained 2 clusters with the highest silhouette coefficient value on the number of clusters 2, namely 0.61534. The number of members in Cluster 1 is 84 MERS-CoV DNA sequences and the number of members in Cluster 2 is 16 MERS-CoV DNA sequences.
\end{abstract}

Key Words : MERS-CoV, Clustering, Partitioning Around Medoid (PAM)

\section{PENDAHULUAN}

Middle East Respiratory Syndrome Coronavirus (MERS-CoV) merupakan suatu penyakit saluran pernapasan yang disebabkan oleh corona virus. MERS-CoV merupakan virus yang menular dari unta ke 
manusia, bahkan baru-baru ini ditemukan bahwa penyakit ini dapat menular dari manusia ke manusia. Berdasarkan laporan WHO, sejak September 2012 sampai dengan September 2013 telah ditemukan 130 kasus konfirmasi MERS-CoV dengan 58 kematian. Artinya sebanyak 44,6\% manusia yang terjangkit virus ini meninggal dunia [1]. Lebih lanjut, WHO menyatakan bahwa selama 2015, National Focal Point (NFP) Arab Saudi mencatat sebuah tambahan 149 kasus infeksi MERS$\mathrm{CoV}$, termasuk 64 orang yang meninggal, dari total 1.090 pasien infeksi MERS-CoV dengan total 412 pasien telah meninggal [2]. MERS-CoV diduga awalnya berasal dari unta yang hidup di negara-negara Timur Tengah, seperti Arab Saudi, Yordania, dan Yaman. Virus ini merupakan virus yang mudah menular, namun penularannya tidak semudah flu biasa, melainkan virus MERS-CoV lebih rentan menular melalui kontak langsung, misalnya pada orang yang merawat penderita virus MERS-CoV tanpa menerapkan prosedur perlindungan diri terhadap virus dengan baik. Meskipun Indonesia sampai saat ini tercatat belum ada yang menderita virus MERS-CoV, namun pemerintah Indonesia rasanya perlu waspada pada penyakit ini. Mengingat bahwa Indonesia merupakan salah satu negara di dunia yang melakukan ibadah haji ataupun umrah di Arab Saudi, sehingga bukan tidak mungkin jamaah Haji ataupun Umrah dapat terinfeksi virus MERS-CoV ini.

Untuk mengetahui karakteristik penyakit virus MERS-CoV dapat diketahui dengan mengidentifikasikan

DNA (deoxyribonucleic acid). DNA merupakan polimer linier yang tersusun dari monomer nukleotida. Komponen penyusun nukleotida terdiri dari tiga jenis molekul, yaitu gula pentosa (deoksiribosa pada DNA), basa nitrogen, dan gugus fosfat. Basa yang ditemukan pada nukleotida adalah basa purin $($ adenin $=A$, guanin $=G)$ dan basa pirimidin yaitu cytosin $=\mathrm{C}$, tymin $=\mathrm{T}, \quad$ (urasil $=\mathrm{U}$ untuk RNA) [3]. Perbedaan susunan keempat basa itulah yang menyebabkan perbedaan karakteristik di semua makhluk hidup.

Salah satu teknik dalam mengidentifikasi karakteristik makhluk hidup adalah dengan melakukan clustering atau pengelompokkan. Clustering data merupakan salah satu metode dalam data mining yang dapat digunakan untuk memetakan data kedalam kelompok kelompok yang lebih kecil berdasarkan kesamaan karakateristik yang dimilikinya[4]. Clustering dapat dilakukan dengan mengelompokkan DNA menjadi kelompok-kelompok yang memiliki kesamaan sifat dan fungsinya. Salah satu algoritma clustering yang terkenal adalah Partitioning Around Medoid (PAM). Penelitian terdahulu yang menggunakan analisis clustering telah dilakukan oleh A. Bustamam, et, all yang melakukan clustering DNA virus MERS-CoV dengan menggunakan metode K-Mer [2].

Alasan dalam penelitian ini menggunakan Partitioning Around Medoid (PAM) dalam menganalisis klaster adalah karena algoritma ini memiliki kelebihan yaitu hasil proses clustering tidak bergantung pada urutan masuk dataset [5]. Disamping itu, algoritma ini mengatasi sensitif terhadap noise dan outlier, dimana objek dengan nilai yang besar yang memungkinkan menyimpang pada dari distribusi data.

Tujuan dari penelitian ini adalah untuk mengimplementasikan algoritma clustering Partitioning Around Medoid (PAM) dalam mengelompokkan virus MERS-CoV. Diharapkan penelitian ini dapat memberikan informasi kesamaan karakteristik virus MERS-CoV yang terjangkit di beberapa negara. Sehingga dapat memberikan informasi dalam pembuatan antivirus atau vaksin untuk 
menyembuhkan manusia yang terjangkit virus MERS-CoV.

\section{METODE PENELITIAN}

Pendekatan penelitian yang digunakan dalam penelitian ini adalah pendekatan studi literatur deskriptif kuantitatif. Pada studi literatur, dilakukan pengumpulan bahan-bahan pustaka yang mendukung dalam penyelesaian topik penelitian ini. Sedangkan untuk pendekatan deskriptif kuantitatif mencakup mengolah, menganalisa dan menginterpretasikan data sesuai dengan kebutuhan peneliti.

Pada penelitian ini data yang digunakan adalah 100 data DNA virus MERS-CoV yang diperoleh dari National Center for Biotechnology Information (NCBI) dalam laman www.ncbi.nlm.nih.gov. Barisanbarisan DNA yang diperoleh berupa FASTA dan berjenis complete genome. Complete genome dipilih karena diharapkan mampu memberikan informasi genetik yang lebih banyak.

Sistem pengkodean protein berdasarkan kombinasi dari nukleotida yang ada karena 20 asam amino tidak mungkin dikendalikan oleh empat jenis nukleotida. Terdapat empat jenis basa nitrogen pada DNA (A, C, G, dan T). Jika sebuah kodon hanya dapat mengkode empat asam amino. Jika sebuah kodon memiliki dua basa, maka hanya 16 asam amino yang dapat dikodekan sehingga jumlah tersebut belum dapat mewakili 20 asam amino.

Akan tetapi, jika kodon merupakan tiga basa, maka terdapat 64 kode yang mungkin berkombinasi sehingga jumlah tersebut diduga sudah dapat mewakili 20 asam amino. Variabel penelitian yang digunakan pada penelitian ini adalah 64 kode asam amino yang diperoleh dari ekstraksi ciri DNA MERS-CoV dengan menggunakan metode n-mers frequency. 64 kode asam amino tersebut dapat dilihat pada Gambar 1.

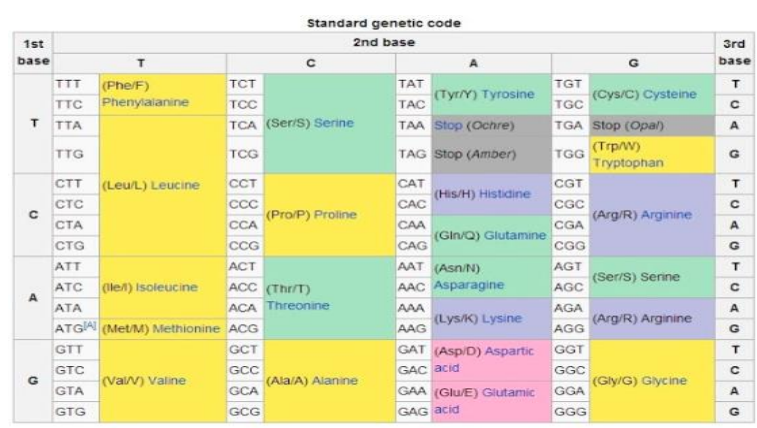

Gambar 1. 64 Kode Asam Amino

Sumber: nafium.com

Metode atau algoritma yang digunaka pada penelitian ini adalah algoritma clustering Partitioning Around Medoid (PAM). Algoritma clustering Partitioning Around Medoid (PAM) bertujuan untuk clustering DNA MERS-CoV berdasarkan 64 asam amino yang diperoleh dari ektraksi ciri DNA MERS-CoV. Tahapan pertama yang dilakukan dalam clustering DNA MERS$\mathrm{CoV}$ adalah melakukan ekstraksi ciri pada DNA MERS-CoV dengan menggunakan metode $n$-mers frequency.

Pada proses ekstraksi ciri $n=3$ sehingga pola kemunculannya adalah $4^{3}=64$ sehingga diperoleh 64 asam amino yang menjadi variabel pada penelitian ini. Langkah selanjutnya adalah melakukan proses normalisasi data untuk menghindari dimensi data yang terlalu besar ataupun terlalu kecil. Proses normalisasi data dilakukan dengan menggunakan min-max normalization. Setelah data sudah normal, maka langkah selanjutnya dilakukan proses clustering dengan menggunakan algoritma clustering Partitioning Around Medoid (PAM).

Pada proses clustering dengan algoritma PAM langkah pertama yang dilakukan adalah menginisialisasi pusat cluster sebanyak $k$ (jumlah cluster) dimana nilai $k$ diperoleh dengan menggunakan average silhouette. Kemudian dilakukan pengukuran jarak dengan menggunakan Euclidean distance serta menentukan secara acak objek pada masing-masing cluster sebagai kandidat medoid baru. 
Hitung jarak setiap objek yang berada pada masing-masing cluster dengan kandidat medoid baru.

Kemudian, hitung total simpangan $(S)$ dengan menghitung nilai total distance baru dikurang total distance lama. Jika $S<0$, maka tukar objek dengan data cluster untuk membentuk sekumpulan $k$ objek baru sebagai medoid. Perulangan didasarkan pada terjadinya perubahan medoid. Jika tidak terjadi perubahan medoid maka iterasi berhenti dan didapatkan cluster beserta anggota cluster masing-masing.

Pada penelitian ini, alat bantu yang digunakan yaitu software RStudio 1.1.456 dan notepad. Adapun diagram alur penelitian ini sebagai berikut:

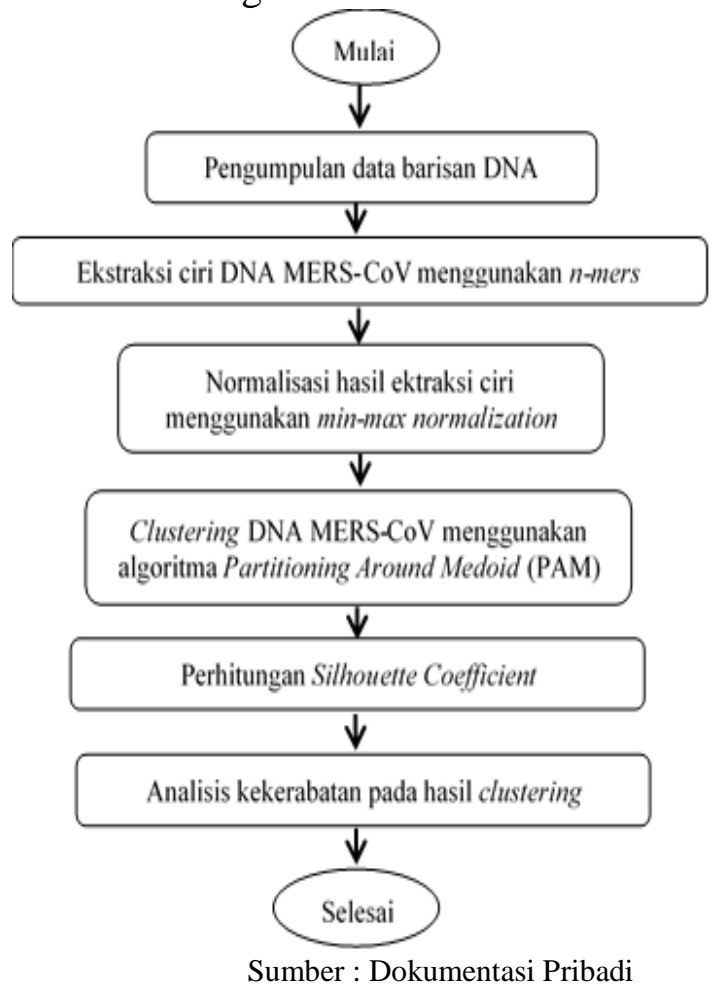

Gambar 2. Diagram Alur Penelitian

\section{HASIL DAN PEMBAHASAN}

Penerapan algoritma clustering Partitioning Around Medoid (PAM) dalam clustering virus MERS-CoV dilakukan dengan langkah-langkah sebagai berikut:
1. Pada tahap pertama, dilakukan pengambilan data berupa 100 data DNA virus MERS-CoV yang diperoleh dari National Center for Biotechnology Information (NCBI) dalam laman www.ncbi.nlm.nih.gov. Barisan-barisan DNA yang diperoleh berupa FASTA dan berjenis complete genome, complete genome dipilih karena diharapkan mampu memberikan informasi genetik yang lebih banyak.

2. Pada tahap kedua, barisan DNA yang diperoleh pada Gen Bank NCBI di situs http://www.ncbi.nlm.nih.gov memiliki bentuk dengan format FASTA (string), sehingga perlu untuk mengubah data tersebut ke dalam bentuk numerik. Mengubah data dalam bentuk string menjadi numerik dilakukan dengan ekstraksi ciri menggunakan n-mers frequency. Pada penelitian ini, ektraksi ciri DNA akan dilakukan dengan melihat pola setiap susunan 4 pasangan nukleotida yang terdiri dari Adenine (A), Guanine (G), Thymine (T), dan Cytosine (C). Pola kemunculannya adalah $4^{n}$ dengan $n \geq 1$ dimana $n$ elemen bilangan bulat positif (Liu, et.al., 2012). Pada proses ekstraksi ciri, $n=3$ dengan pola kemunculannya adalah $4^{3}=64$, sehingga diperoleh 64 asam amino yang menjadi variabel pada penelitian ini. Hasil ekstraksi ciri barisan DNA MERS_CoV dengan menggunakan n-mers frequency yang dibantu oleh software $R$ Studio dapat dilihat pada Gambar 3 merupakan potongan hasil ektrasksi dari barisan DNA virus MERS-CoV. 


\begin{tabular}{|c|c|c|c|c|c|c|c|c|c|}
\hline$x \neq$ & aaa & aac $\approx$ & aag & aat & aca $₹$ & acc $\neq$ & acg & act & aga \\
\hline 1 & 581 & 449 & 516 & 619 & 567 & 349 & 199 & 635 & 436 \\
\hline 2 & 581 & 449 & 516 & 619 & 567 & 349 & 199 & 635 & 436 \\
\hline 3 & 571 & 438 & 511 & 603 & 555 & 344 & 201 & 626 & 427 \\
\hline 4 & 571 & 438 & 511 & 603 & 555 & 344 & 201 & 626 & 427 \\
\hline 5 & 571 & 438 & 511 & 602 & 554 & 345 & 201 & 626 & 426 \\
\hline 6 & 571 & 437 & 511 & 604 & 554 & 345 & 201 & 624 & 428 \\
\hline 7 & 571 & 438 & 512 & 601 & 554 & 345 & 201 & 626 & 427 \\
\hline 8 & 570 & 437 & 512 & 602 & 554 & 345 & 201 & 626 & 425 \\
\hline 9 & 571 & 437 & 512 & 603 & 554 & 345 & 201 & 626 & 427 \\
\hline 10 & 574 & 437 & 512 & 603 & 554 & 344 & 201 & 628 & 427 \\
\hline 11 & 574 & 438 & 509 & 597 & 561 & 343 & 198 & 622 & 426 \\
\hline 12 & 579 & 439 & 516 & 613 & 558 & 346 & 202 & 632 & 434 \\
\hline 13 & 578 & 441 & 515 & 612 & 556 & 345 & 203 & 632 & 434 \\
\hline 14 & 571 & 436 & 508 & 600 & 551 & 341 & 202 & 629 & 424 \\
\hline 15 & 567 & 436 & 508 & 602 & 552 & 342 & 202 & 628 & 425 \\
\hline 16 & 587 & 447 & 517 & 625 & 563 & 349 & 204 & 632 & 438 \\
\hline 17 & 588 & 447 & 517 & 624 & 563 & 347 & 204 & 632 & 437 \\
\hline
\end{tabular}

Sumber: Dokumentasi Pribadi

\section{Gambar 3. Potongan Hasil Ekstraksi Ciri 100 Barisan DNA MERS-CoV Menggunakan Software RStudio}

Nilai minimum hasil ekstraksi ciri DNA MERS-CoV adalah 116 dan nilai maksimum hasil ekstraksi ciri DNA MERS-CoV adalah 887. Hasil perhitungan ekstraksi ciri dengan menggunakan n-mers frequency pada 100 barisan DNA MERS-CoV.

3. Pada tahap ketiga, dilakukan proses normalisasi dengan menggunakan minmax normalization dari data 100 barisan DNA MERS-CoV yang telah dilakukan ekstraksi ciri DNA MERS-CoV. Proses perhitungan normalisasi pada penelitian ini menggunakan bantuan software RStudio dengan nilai maksimum terbaru adalah 1 dan nilai minimum terbaru adalah 0 . Hasil normalisasi dari ekstraksi ciri DNA yang dibantu dengan menggunakan software RStudio dapat dilihat pada Gambar 4.

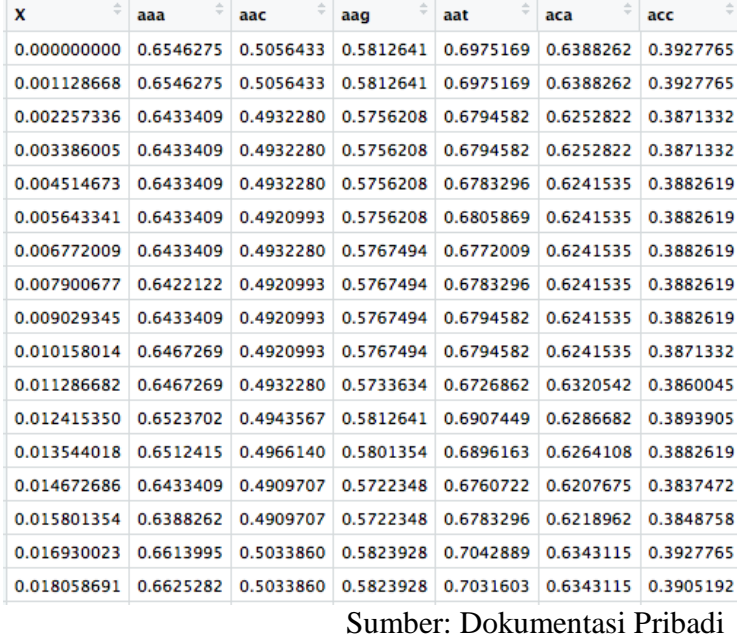

Gambar 4. Potongan Hasil Normalisasi dari Ekstraksi Ciri DNA MERS-CoV yang dibantu dengan Menggunakan Software RStudio

Hasil 100 barisan DNA MERS-CoV yang telah diekstraksi ciri dan dinormalisasi kemudian akan menjadi matriks objek $(\boldsymbol{x})$ yang menjadi input pada saat algoritma PAM.

4. Pada tahap keempat, dilakukan clustering barisan DNA MERS-CoV menggunakan algoritma PAM clusering. Hasil clustering barisan DNA MERS-CoV menggunakan algoritma PAM clustering diperoleh 2 cluster dengan medoid dari masing-masing cluster dapat dilihat pada Gambar 5. 


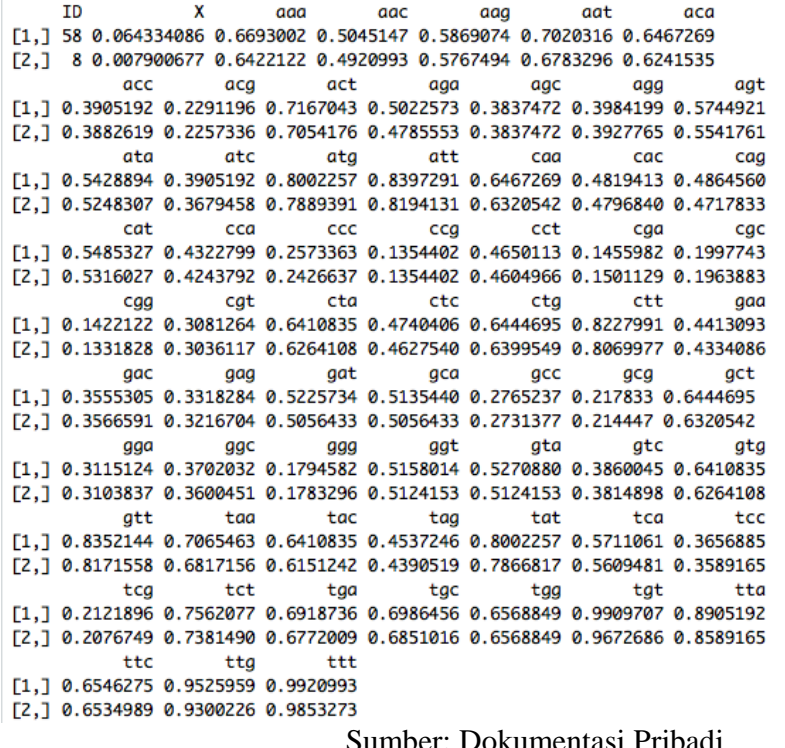

\section{Gambar 5. Medoid dari Hasil Clustering} Barisan DNA MERS-CoV

Pada Gambar 5. terlihat bahwa medoid atau pusat cluster dari cluster 1 adalah barisan DNA MERS-CoV M58 yaitu barisan DNA MERS-CoV yang berasal dari Qasim pada tahun 2016 dan medoid dari cluster 2 adalah barisan DNA MERSCoV M8 yaitu barisan DNA MERS-CoV yang berasal dari Nigeria pada tahun 2016.

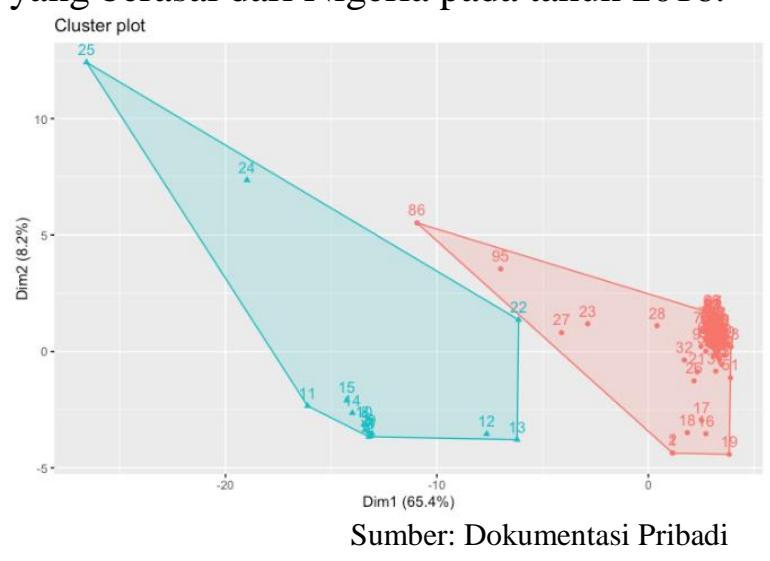

\section{Gambar 6. Hasil Clustering Barisan DNA MERS-CoV menggunakan Algoritma PAM}

5. Pada tahap kelima, dilakukan perhitungan Silhouette Coefficient dan diperoleh lebar average silhouette pada masing-masing cluster yaitu untuk cluster 1 diperoleh nilai average silhouette 0.6140725 , sedangkan nilai average silhouette pada cluster 2 yaitu 0.6219940. Pengujian pengaruh jumlah cluster dilakukan dengan memasukkan nilai $k$ yang berbeda-beda yaitu $k=1,2, \ldots, 10$. Nilai silhouette coefficient yang tertinggi berada pada jumlah cluster 2 yaitu 0,61534 dapat dilihat pada Gambar 7.

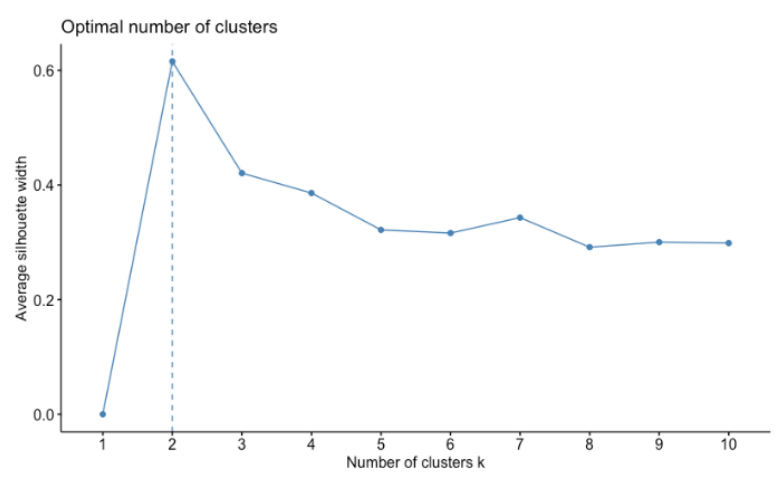

Sumber: Dokumentasi Pribadi

Gambar 7. Grafik hasil pengujian pengaruh jumlah cluster terhadap Silhouette Coefficient

6. Pada tahap keenam, dilakukan analisis dari hasil clustering dengan menggunakan algoritma PAM clustering. Pada Gambar 8 terlihat bahwa medoid atau pusat cluster dari cluster 1 adalah barisan DNA MERSCoV m58 yaitu barisan DNA MERS$\mathrm{CoV}$ yang berasal dari Qasim pada tahun 2016 dan medoid dari cluster 2 adalah barisan DNA MERS-CoV m8 yaitu barisan DNA MERS-CoV yang berasal dari Nigeria pada tahun 2016. Maximum dismilarity adalah nilai ketidakmiripan antar cluster. Nilai maximum dismilarity dari cluster 1 adalah 0,09208162, sedangkan nilai maximum dismilarity dari cluster 2 adalah 0,09354338 Average dissmilarity merupakan nilai ketidakmiripan antar objek di dalam cluster yang sama. Semakin kecil nilai average dismilarity maka semakin baik cluster yang terbentuk. Nilai average 
dissmilarity dari cluster 1 adalah 0,3518736, sedangkan nilai average dissmilarity dari cluster 2 adalah 0,3044489. Kemudian, diameter menunjukkan panjang diameter dari masing-masing cluster. Diameter dari cluster 1 adalah 0,1291228, sedangkan diameter dari cluster 2 adalah 0,1206725 . Separation atau pemisah pada cluster 1 dan 2 memiliki nilai yang sama yaitu 0,0262764 .

\section{size max_alss av_alss alameter separation \\ $\left[\begin{array}{llllll}{[1,]} & 84 & 0.09208162 & 0.03518736 & 0.1291228 & 0.0262764\end{array}\right.$ \\ $\left[\begin{array}{lllllll}{[1,]} & 16 & 0.09354338 & 0.03044489 & 0.1206725 & 0.0262764\end{array}\right.$ \\ Gambar 8. Karakteristik Hasil Clustering menggunakan Algoritma PAM Clustering}

\section{Tabel 1. Hasil Clustering Barisan DNA MERS-CoV menggunakan Algoritma PAM}

\begin{tabular}{|c|c|c|}
\hline Cluster & Anggota & Jumlah \\
\hline 1 & $\begin{array}{l}\text { M1, M2, M16, M17, M18, } \\
\text { M19, M20, M21, M23, M26, } \\
\text { M27, M28, M29, M30, M31, } \\
\text { M32, M33, M34, M35, M36, } \\
\text { M37, M38, M39, M40, M41, } \\
\text { M42, M43, M44, M45, M46, } \\
\text { M47, M48, M49, M50, M51, } \\
\text { M52, M53, M54, M55, M56, } \\
\text { M57, M58, M59, M60, M61, } \\
\text { M62, M63, M64, M65, M66, } \\
\text { M67, M68, M69, M70, M71, } \\
\text { M72, M73, M74, M75, M76, } \\
\text { M77, M78, M79, M80, M81, } \\
\text { M82, M83, M84, M85, M86, } \\
\text { M87, M88, M89, M90, M91, } \\
\text { M92, M93, M94, M95, M96, } \\
\text { M97, M98, M99, M100 }\end{array}$ & 84 \\
\hline 2 & $\begin{array}{l}\text { M3, M4, M5, M6, M7, M8, } \\
\text { M9, M10, M11, M12, M13, } \\
\text { M14, M15, M22, M24, M25 }\end{array}$ & 16 \\
\hline
\end{tabular}

Pada Tabel 1 terlihat bahwa jumlah anggota pada Cluster 1 adalah 84 barisan DNA MERS-CoV dan jumlah anggota pada Cluster 2 adalah 16 barisan DNA MERS-CoV. Cluster 1 terdiri dari barisan DNA MERS-CoV yang berasal Kenya tahun 2018, Ethiopia tahun 2017, Egypt tahun 2018, China tahun 2018, Hu-France tahun 2013, England tahun 2013, Thailand tahun 2015, Korea Selatan tahun 2015, Qatar tahun 2015, Riyadh tahun 2018, Riyadh tahun 2016, Riyadh tahun 2015, Jeddah tahun 2017, Riyadh tahun 2016, Qasim tahun 2016, Madinah tahun 2016, Riyadh tahun 2017, Artawiyah tahun 2016, Jeddah tahun 2016, Taif tahun 2014, Riyadh tahun 2015, Jeddah tahun 2015, Najran tahun 2015, Kharj tahun 2015, dan Khobar tahun 2015. Sedangkan, Cluster 2 terdiri dari barisan DNA MERS-CoV yang berasal Nigeria tahun 2016, Nigeria tahun 2015, Burkina tahun 2015, Morocco tahun 2015, dan Hu-France tahun 2013.

\section{SIMPULAN}

Pada penelitian ini dapat disimpulkan:

1. Algoritma PAM dapat diimplementasikan pada clustering barisan DNA MERS-CoV. Data barisan DNA MERS-CoV yang digunakan sebanyak 100 data set. Proses awal yang dilakukan adalah dengan data set yang memiliki bentuk dengan format FASTA (stringke dalam bentuk numerik. Mengubah data dalam bentuk string menjadi numerik dilakukan dengan ekstraksi ciri menggunakan n-mers frequency. Kemudian, dilakukan proses normalisasi dengan menggunakan minmax normalization, selanjutnya dilakukan clustering barisan DNA MERS-CoV menggunakan algoritma PAM clusering. Setelah itu, menghitung nilai silhouette coefficient untuk mengetahui kualitas cluster yang dihasilkan.

2. Implementasi algoritma PAM terhadap barisan DNA MERS-CoV diperoleh 2 cluster dengan nilai silhouette coefficient yang tertinggi berada pada jumlah cluster 2 yaitu 0,61534. Jumlah anggota pada Cluster 1 adalah 84 barisan DNA MERS-CoV dan jumlah anggota pada Cluster 2 adalah 16 
barisan DNA MERS-CoV. Kemudian, medoid atau pusat cluster dari cluster 1 adalah barisan DNA MERS-CoV M58 yaitu barisan DNA MERS-CoV yang berasal dari Qasim pada tahun 2016 dan medoid dari cluster 2 adalah barisan DNA MERS-CoV M8 yaitu barisan DNA MERS-CoV yang berasal dari Nigeria pada tahun 2016.

\section{DAFTAR PUSTAKA}

[1] K. Kamal, K. A. Sugeng, and T. Siswantining, "Implementation algorithm modification maximum standard deviation reduction in graph clustering using matrix complement as input," AIP Conf. Proc., vol. 2023, 2018.

[2] A. Bustamam, E. D. Ulul, H. F. A. Hura, and T. Siswantining, "Implementation of hierarchical clustering using k-mer sparse matrix to analyze MERS-CoV genetic relationship," AIP Conf. Proc., vol. 1862, no. July, 2017.

[3] R. V. S. A. Morihito et al., "Identification of Changes of DNA Structures on Cancer Cll Form Using Graph Decomposition," J. Ilm. Sains, vol. 17 No.2, pp. 153-160, 2017.

[4] T. Taslim and F. Fajrizal, "Penerapan algorithma k-mean untuk clustering data obat pada puskesmas rumbai," Digit. Zo. J. Teknol. Inf. dan Komun., vol. 7, no. 2, pp. 108-114, 2016.

[5] L. P. Rizby, Marji, and L. Muflikhah, "Clustering Pasien Kanker Berdasarkan Struktur Protein Dalam Tubuh," J. Pengemb. Teknol. Inf. dan Ilmu Komput. Univ. Brawijaya, vol. 2, no. 10, pp. 3810-3816, 2018. 